theme 3

identity

author(s) strand 1

design process and practice
Saniye Fışgın fisgin@itu.edu.tr Humanur Bagli bagli@itu.edu.tr Istanbul Technical University
Blucher Design Proceedings Dezembro de 2014, Número 5, Volume 1

\title{
The effect of cultural roots on service design: Turkey as a case
}

The aim of this paper is to frame the issue of service and its connection with the disciplines of design in Turkey, its potentials and actors with a specific focus on the cultural influences and roots. This paper is a part of ongoing thesis research about service design in Turkey.

In the first part of the research the position of service sector in Turkey is summarized from past to present and the sectors which have a dimension of service like tourism, trade, health and construction sector in Turkey are discussed. In the second part, potentials of service design in Turkey are mentioned by making connections to the Turkish hospitality, history and demographic structure. It is claimed that there are huge potentials in the Turkish culture to design creative service businesses, especially in the hospitality sector. However still, it can be predicted that a company which has a notion of service design, can also use the same know-how when developing their own designed items. Therefore, we can easily say that there is a strong connection among service, design and culture, which are the main axes of this study.

keywords service design, culture, rituals, turkish culture

\section{Introduction}

"Services are unusual in that they have impact, but no form. Like light, they can't be physically stored or possessed and their consumption is often simultaneous with their production." (Shostack, 2000: 133-139).

However, Mager (2008) thinks that; service design stands in the tradition of product and interface design, enabling the transfer of proven analytical and creative design methods to the world of service provision (2008). This is a proof that the professions of design, with a broadened perspective are effective on the decisions and productions about service design. Since its first emergence in Turkey, the issue of design and its role in industry are always hot topics for designers. As seen in the economic data, Turkey is a country where industrial productions are limited, however there are too many good design schools. $\operatorname{Er}(2004)$ mentioned that there are several specialties of designers in the countries like Turkey such as; being problem solvers for the problems of social and economic development, having a new perspective in design thinking which is far away from industrial production (Er, 2004). 


\section{Service sector in Turkey: summary}

One example from Turkey is Brisa Akademi (a department of Brisa which organize several educational events for the company members). According to Bayman, a representative of Brisa (Turkish rubber tire producer), they had several workshops with Ayșe Birsel (Turkish famous industrial product designer) about innovation and creativity. After these workshops they had created many business ideas. Even though Bridgestone is a rubber tire producer, their new created ideas were all service business ideas. (Bayman, 2013).

In recent years, some companies that deliver the service of design consultancy and design specifically services such as I am Istanbul and Fjord in Turkey. Companies which have a service aspect in its work definition interested in service design and employ service designers, such as Turkcell which is a member of Service Design Network, also Turkish Airlines. This is a sign that service sector and design in Turkey has started to be officially discussed, developed and performed with different agents.

MUSIAD (Independent Industrialists and Businessmen's Association) determined several services which lead to successful and strong businesses in Turkey; First, the knowledge based services such as architecture and engineering, technical consultancy, constructing Information technologies and the traditional services that are transporting services and tourism services (Taşkesenoğlu, 2009).

\subsection{The knowledge based services}

Architecture and engineering: The creative services in the construction industry are architecture, interior design, landscape design, city planning etc. In the collaboration processes between construction industry and construction based industries (like lighting devices producers, bathroom fixtures producers etc.), the discipline of industrial design and interior design steps in. However, we cannot assume that the issue of design in this sector is prominent, the dominancy of standardized services in this sector is obvious here.

Information technologies: It is the area where service aspect is very important. Turkcell is the biggest telecommunication provider in Turkey. They have also important investments to creative industries. According to Fjord, one of the first service design firms in Turkey, they use their service and interaction design services to contribute the quality of their job (Fjord Turkey, n.d.).

\subsection{Traditional Services}

Transportation services: As for the transportation services, a worldwide known company, Turkish Airlines which is a member Star Alliance is very successful in Turkey. Turkish Airlines have several awards such as "Best Airline in Europe", "Best Airline in Southern Europe", "Best Business Class Catering" all related with the quality they provide related with service aspect.

Together with the airlines, the quality of intercity busses in Turkey is unique, especially the food serving tradition compared to its counterparts in Europe and USA. It is also an interesting example of how serving culture is embedded in Turkish businesses.

Tourism services: Tourism has a big role in Turkey's economy, because of its special geopolitical, historical and cultural importance. However the expertise of design is limited in this sector because most of the services are standardized to keep up with the global needs. 


\section{The effects of culture in service sector in Turkey}

Because "service" is a qualitative issue, it is closely connected to cultural values. In Turkey, service sector has great potentials in the processes of business as exemplified above. In this study, we are going to try to find roots of these potentials in Turkish culture and elaborate the future of service sector under the light of this analysis.

\subsection{Cultural Diversity, Different Religions, Different Lifestyles}

Anatolia is one of the most important civilization centers since the beginning of the history. So many different nations and ethnic groups have lived and there has been so many life styles existed for centuries. Depending on all these historical and geographical movements, Turkey became a panaroma of so many different life styles, religious beliefs and ethnic groups in Turkey (Aka, 2012).

Mager thinks that with service design, designers design experiences (Mager, n.d.). Similarly, different lifestyles, ethnic and religious traditions create so many different experiences, such as traditional weddings, hamam culture (fig.1), different kinds of dances, a rich cousine etc. It can be predicted that with the inspiration of the richness of all these experience and influences, so many successful service businesses can be designed. From the hospitality sector to technology, this cultural diversity can help Turkish Service Designers to design more creative and more emphatic services.

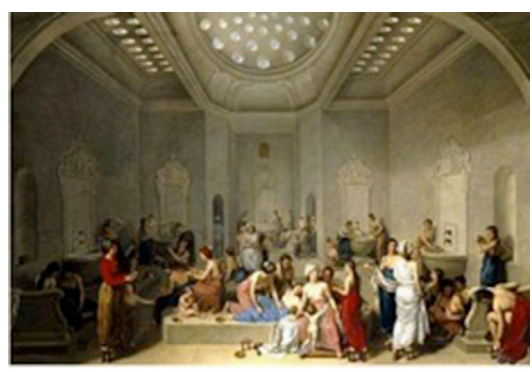

Figure 1.

A Female Turkish Bath or Hamam Painting (1785) by Jean Jacques Francois Lebabier (Most Famous Paintings, n.d.).

\subsection{Life at Home and Outside Home}

If we try to define Turkish Culture, like any culture, it is very easy to make some generalizations, because all cultures are ideological constructs in one way or other. However some of these generalizations are so superficially made, some are worth thinking in the light of some capacities about the issue of service and design.

Turkish social support and help tradition date back to ancient times. Yazılıtaş defines (2002) this tradition in seven parts; serving to poor, serving to guests, help and support in weddings, funerals and in military services.

Yazilitaș mentions about some places like caravanserais (early forms of hotels) in the villages of the Turks before Islam. He tells about this places are for free or very cheap for the visitors who came to the villages. (Yazılıtaș, 2002). The culture of caravanserais can be regarded as the early forms of tourism and hotels in Turkey, still influential in the culture of tourism in Turkey.

Also, there are so many active and powerful NGOs in Turkey, such as Kızılay (Red 
theme 3

identity

Figure 2.

Some packaging examples of dried fruits. (Malatya Pazarı, n.d.) strand 1

design process and pratice

Crescent), AKUT, LOSEV, and TOGV. All these institutions are also somehow part of the old helping tradition in Anatolian culture, as continuation of old organizations called Vakf (charitable foundations) in Ottoman times.

The rich and various kitchen culture in Turkey can also be connected to the culture of hospitality (Sürücüoğlu and Akman, 1998). This aspect of Turkish Culture is directly applicable in sectors like Tourism and restaurants. Turkish Cousine is famous not only because it has a great and original variety of food, but also for its unique "serving" rituals coming together as an indispensable part of it.

As common furniture for Turkish Houses, convertible sofa-beds are signs and also unique outcomes of the Turkish hospitality. This comes from the tradition that Turkish people are always ready to host a guest in their houses (Çelikoğlu, 2011).

The issue of guest-room in Turkish Culture is also unique, because the special place called "Guest-room" is always closed and the doors are opened only when a guest visits the house. All these unique solutions coming from the traditional aspects of culture can be regarded as roots of the existing success in service sector in Turkey, also new starting points to design creative solutions to service problems.

\subsection{Nomadic Culture and Geographical Position of Anatolia}

For most of the Anatolian population it has been said to have origins depending on nomadic culture. Turks have a unique culture because of the 3500 years of steppe life and nomadic origins. Their life style not only affected their economic conditions and activities but also their faith, system of thought and values (Sayılır, 2012).

Çevik and Kaya indicate that there is a huge progress in the logistics sector in Turkey recently. Because of the geographical position, it is like a bridge between Middle Eastern countries, other Turkish republics and Europe. (Çevik \& Kaya, 2010).

Toprak asserts that the relation to Silk Road is very effective on Turkish culture. While the people in Anatolia were trading, Silk Road supported the connection between all Turkish nations. It was like a network on all the Turkish countries, while the traders were bringing the goods (Toprak, 2008). Silk Road is a sign that trade is an important fact in Turkish culture from the antique time.

Turkey with its socio-cultural and logistic importance is like a bridge in the world. This reminds us the famous slogan of Turkey in one of the old Olympic Game organizations: "Let's meet where the continents meet!" This situation is very important for sectors like transportation (especially Turkish Airlines, trade etc.)
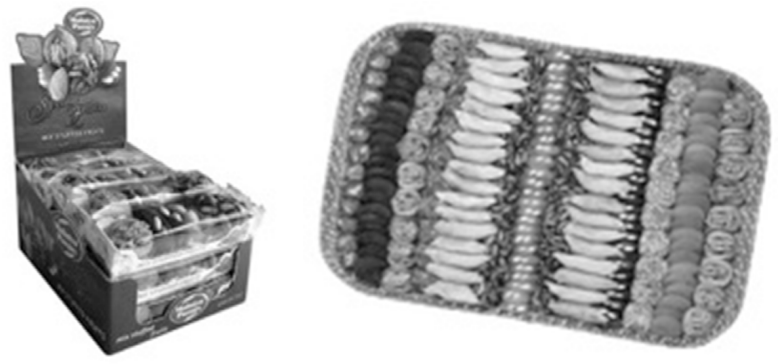
Nomadic Culture is also one of the sources of the uniqueness for the food culture in Turkey; that led to the invention of dried foods (fig. 2), cheese etc. with the characteristic of durability. Just to give an example about the potentials about service design, that might give ideas to develop new ways to design food packages, also the food itself with the aspect of preservation.

\section{Conclusion}

Although fairly old in practice, service design is a new paradigm in the literature of design and some related fields like marketing. Turkey has always been popular in sectors dominated in terms of service like tourism, trade etc. However, in this new era of service design discussed together with experience design and more generally design thinking, Turkey like any other culture should look at its cultural potentials and find new connections to be transferred and transformed to be experienced in service by design. In a cultural and technological climate where immateriality and social media are dominant, the emphasis on service fed by the cultural values becomes prominent and also necessary.

This also gives a way to look for more sustainable and environmentally conscious solutions to the problems design seeks for.

In this article, we aimed to look for the relation between design and service sector in Turkey with a special focus to cultural values. Both potentials and abilities about service design in Turkey are discussed and exemplified.

We think that the rich culture of Anatolia, different rituals of Islam and the social helping tradition of Turkey inherited from the past and still living in daily life are the cultural potentials for a creative, productive service design, together with the practices of design disciplines.

Deep analysis of cultural values for each community/nation/religion etc. with a good connection to the needs of service is a way towards evaluating original experiences in terms of design.

\section{References}

Aka, M. (2012) 'Languages and Ethnic Groups in Turkey' International Journal of Turkish Literature Culture Education. 1 (1): pp. 293-297.

Bayman, H. (2013) Brisa Akademi. Presented Istanbul Innovation Week 2013/Istanbul. Celikoglu, O. (2010) 'Cekyatın öyküsü :Türkiye'de toplumsal değișime tanıklık eden bir mobilya' Graduate. ITU.

Cevik, S. Kaya, S. (2010) Türkiye'nin lojistik potansiyeli ve Izmir'in lojistik faaliyetleri açısından durum analizi. İmir: Izmir Ticaret Odası.

Er, A. (2004) Economy of Industrial Design in the Periphery. Paper presented Sao Paolo: P \& D Design 6 Congresso Brasilerio De Pesquisa E Desenvolvimento Em Design.

Fjord. 'Istanbul Studio' http:// http://www.fjordnet.com/offices/istanbul/ (accessed: 26/04/2014).

Mager, B. n.d. Service Design as An Emerging Field. n.p. Service Design Network. http:// service-design-network.org/system/files/med ia/Mager_Service\%20Design\%20as\%20 an\%20emerging\%2of ield. PDF. (accessed: 24/05/2013).

Mager, B. (2008) 'Service Design' Design Dictionary. Erlhoff M and Marshall T. eds. Basel Boston Berlin: Birkhäuser Basel.

Malatya Pazarı. 'Products'http://www.malatyapazari.com.tr/products.php (accessed: 26/04/2014). 
Sayılır, S. (2012) 'Nomadism and Semi-Nomadism Issue and Differentiation of the Nomads in Terms of Geography' Journal of Turkish Studies. 12 (1): pp. 563-580.

Shostack, G.L. (1984) 'Designing Services that Deliver' Harvard Business Review. 1984 pp. 133-139.

Sürücüoğlu, M.S. Akman, M. (1998) 'Türk Mutfağının Tarihsel Geliş̧imi ve Bugünkü Değişim Nedenleri' Standart Dergisi. 439 pp. 42-53.

Taşkesenoğlu, Z. (2009) Hizmet Sektör Raporu. . Istanbul: Müstakil İş Adamları Derneği (MÜSIAD). PDF.

Most Famous Painting. 'Female Turkish Bath or Hammam 1785' http://www.mostfamous-paintings.org/A-Female-Turk \%2oish-Bath-or-Hammam--1785.html (accessed: 07/01/2014).

Toprak, A. (2008) Silk Road In The Cultural Interaction of East and West (From the Beginning Till the End of Gokturk Period. Paper presented Ankara: Gazi University. Yazılıtaș, N. (2002) 'Türk Toplum Hayatında Sosyal Yardımlașma ve Dayanıșmanın Tarihi Temellerine Bir Bakıș’ Nüsha. 2 (5): pp. 163-171. 